\title{
Ahlaki İkilem Tekniğine Dayalı Çalışma Yaprağına İlişkin 7. Sınıf Öğrencilerinin Görüşleri: Farklılıklara Saygı Değeri*
}

\section{Views of Seventh Grade Students about Work Sheets based on the Moral Dilemma Technique: The value of Respect for Diversity}

\author{
Emine Yalman, ${ }^{a}$ Vedat Aktepe, ${ }^{\text {b*** }}$ Abdülkadir Uzunöz ${ }^{\mathrm{c}}$ \\ ${ }^{a}$ Öğrt., Milli Eğitim Bakanlığı, İstiklal Ortaokulu, 50200, Nevşehir/Türkiye. \\ ORCID: 0000-0003-3337-0449
}

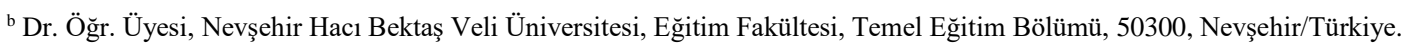
ORCID: 0000-0001-5259-9340

c Doç. Dr., Nevşehir Hacı Bektaş Veli Üniversitesi, Eğitim Fakültesi, Sosyal Bilimler ve Türkçe Eğitimi, 50300, Nevşehir/Türkiye. ORCID: 0000-0002-4130-4612

\section{MAKALE BILGİSI}

Makale Geçmişi:

Başvuru tarihi: 15 Kasım 2017

Düzeltme tarihi: 16 Aralık 2017

Kabul tarihi: 20 Aralık 2017

\section{Anahtar Kelimeler: \\ Sosyal Bilgiler \\ Değer \\ Değer Öğretim \\ Ahlaki İkilem \\ Sayg1}

\section{ARTICLE INFO}

\section{Article history:}

Received 15 November 2017

Received in revised form 16 December 2017

Accepted 20 December 2017

\section{Keywords:}

Social Studies

Value

Value Teaching

Moral Dilemma

Respect

\section{ÖZ}

$\mathrm{Bu}$ araştırmada ahlaki ikilem tekniğine dayalı hazırlanan farklılıklara saygı değeri çalışma yaprağındaki sorulara verilen öğrenci cevaplarının tespit edilmesi amaçlanmıştır. Nitel bir çalışma olan bu araştırmada örnek olay yöntemi kullanılmıştır. Araştırma bütüncül tek durum deseni ile yürütülmüştür. Araştırma grubunu Nevşehir merkezindeki bir devlet okulunun yedinci sınıfinda öğrenim gören yirmi yedi öğrenci oluşturmaktadır. Veri toplama aracı olarak araştırmacılar tarafından hazırlanan farklılıklara saygı çalışma yaprağı kullanılmıştır. Elde edilen verilere içerik analizi yapılmıştır. Araştırma bulgularının iç tutarlığı ve geçerliğini artırmak amacıyla, her bir temanın altında öğrenci görüşlerini yansıtan doğrudan alıntılara yer verilmiştir. Öğrencilerin ahlaki muhakeme sürecinde en etkili faktör olumlu iletişim kurmak olurken, etkisi olan diğer önemli faktörler de empati kurmak ve saygılı olmak olarak belirlenmiştir.

\section{A B S T R ACT}

It is aimed to determine the student responses to questions about The Value of Respect for Diversity in a worksheet that is based on the moral dilemma technique. The research is a qualitative study and case study method is used, and it has been carried out with a holistic single case design. The research group consists of twenty seven students studying in the seventh grade of a public school in central Nevşehir. As data collection tool, worksheets based on the value of Respect for Diversity prepared by the researchers were used. Content analysis was performed on the data obtained. In order to increase the internal reliability and validity of the findings of the study, the students' opinions were given by making direct citations. The most effective factor in their moral reasoning process was positive communication while other important factors were empathy and respect.

\footnotetext{
* Bu çalışma, 20-23 Nisan 2017 tarihlerinde Antalya'da düzenlenen 26. Uluslararası Eğitim Bilimleri Kongresi’nde bildiri olarak sunulmuştur.

** Sorumlu yazar/Corresponding author.

e-posta: vedataktepe@ nevsehir.edu.tr
} 


\section{Giriş}

Değer, Türk Dil Kurumu tarafından hazırlanan güncel Türkçe sözlükte bir şeyin önemini belirlemeye yarayan soyut ölçü bir şeyin değdiği karşılık olarak tanımlanmıştır. Bir varlığın ruhsal toplumsal, ahlaksal ya da güzellik yönünden taşıdığı düşünülen yüksek ya da yararlı nitelik olarak açıklanmıştır (TDK). Znaniecki tarafindan Sosyal Bilgilere kazandırılan değer kavramı Latince güçlü olmak, kıymetli olmak anlamına gelen "Valere" kökünden türemiştir (Bilgin, 1995). Ayrıca bir şeyin sahip olduğu kıymet veya niteliğe değer dediğimiz gibi; kişilerin hayatlarına kılavuzluk eden, bizim hayatlarımızda önem dereceleri olan hedeflerimize de değer adını veriyoruz (Aydın, 2010).Başka bir tanıma göre de bir şeyin aynı türden şeyler arasındaki yerine ve konumuna bizim yüklediğimiz anlamdır (Tepe, 2002). Yani bu tanımdan yola çıkacak olursak bizim için değerli olan bir nesne, cisim ya da mekân başkası için çok sıradan ve değersiz olabilmektedir. Bu durumda bize değeri ifade ederken insanların yaşanmışlıklarının, bireysel farklılıklarının, beklentilerinin, yaşadıkları sosyal-kültürel çevrenin ve ekonomik düzey gibi birçok faktörün değeri tanımlamada ve değer kavramının kişilerde oluşmasında etkili olduğunu göstermektedir. Örneğin: Çocukluğunuzun geçtiği ve içerisinde büyüdüğünüz eviniz sizin için çok değerliyken başkaları için sıradan bir olabilmekte ya da futbolu sevdiğiniz için size verilen futbol topu çok değerliyken futbolla ilgilenmeyen bir arkadaşınız için çok sıradan ve değersiz olabilmektedir. $\mathrm{Bu}$ örnekleme çoğaltılabilir. Yani değerler toplumlara, kültürlere ve kişilere göre değişebilen bir kavramdır. Bu konuda araştırma yapan Ülken (2001) her toplumun ve her kültürün kendi değerleri olduğunu belirtmiştir. Bir başka tanımda ise değer insan, toplum, kurum veya ideolojinin düşünce, hüküm, tutum, davranış ve etkinliklerinde tercih edilen kabul görülen benimsenen arzu edilen ve istenen inanç, yarg1, amaç, hedef, gaye, ölçüt, rehber, kılavuz, standart, kural, duyuş ve düşünceler olarak tanımlanmıştır (Köylü, 2016). Genel olarak değer tanımlarına bakıldığında üzerinde birleşilen kavramlar, inançlar, eğilimler, normatif standartlar ve tutumlardır (Mehmetoğlu, 2006).Yapılan tanımlarda da bu kavramlardan yola çıkılarak genel kabul gören bir tanıma gidilmeye çalışılmıştır (Ulusoy, 2016).

Değerin ne olduğunu anlamak için değerin özelliklerine de değinmek gerekir. Değerlerin özellikleri şöyle sıralanabilir (Kuşdil ve Kağıtçıbaşı, 2000):

(i) Değerler inançlardır.

(ii) Değerler bireylerin amaçlarıyla ve bu amaçlara ulaşmada etkili olan davranış biçimleriyle ilişkilidir.

(iii) Değerler özgür eylem ve durumların üzerindedirler.

(iv) Değerler davranışların, durumların, insanların ve olayların seçilmesini ya da değişimini yönlendiren standartlar olarak işlev görürler.

(v) Değerler kendi aralarında taşıdıkları öneme göre siralanırlar.

(vi) Değerler değişime açık yapılardır.

(vii) Değerler bağlı oldukları kültürlere göre değişir. Hatta ait oldukları kültürlerin içerisinde bile farklılık gösterebilirler.

Geleneksel felsefi anlayışa göre değerler yaradılışta insanda bulunan özelliklerdir. İnsanın görevi bu değerleri ortaya çıkarmaktır, var olan değerin farkına varmaktır (Hökelekli,
2011). İnsanın en değerli kazanımının insanın kendisi hakkında edindiği bilgi olduğunu vurgulayan Sokrates 'kendini bil' diyerek Felsefe'nin insan davranışları üzerindeki etkisini vurgulamıştır (Kale, 2009). Değerlere felsefe açısından bakıldığında da değer çok farklı anlamlar ifade etmektedir. Değer kavramı felsefede değer problemi olarak karşımıza çıkar. "İyi nedir?", "Doğru nedir? ve "Faydalı Nedir?" gibi soruları sormak değer kavramını belli açılardan problem haline getirmiştir (Kuçuradi, 1971). Bu soruna her felsefi yaklaşım kendi bakış açısı ile yaklaşsa da felsefede bu sorunun çözümü noktasında kabul edilen iki yaklaşım vardır. Bunlardan biri değerin zaman içerisinde ve toplumdan topluma değişeceğini ifade ederken ikinci olarak da değerin mutlak olduğu zamana ve topluma göre değişmeyeceği görüşüdür (Toku, 2003). Fakat her iki görüşte de toplumun değerler sistemi olarak kabul edilmiş ve bu sistemin devamlılığının sağlanmasının önemi vurgulanmış sistemin devamlılığında da okulun önemi vurgulanmıştır (Demirel, 2007).

Günümüzdeki teknolojik ve toplumsal alanlarda meydana gelen gelişmeler gençleri olumsuz etkilemekte ve şiddet içerikli sinema, film ve oyunlar gençleri bu hareketlere karşı duyarsızlaştırmaktadır (Tillman, 2000). Değer eğitimiyle bireyde olması istenen değerler, tutumlar kazandırılarak değer bakımından olgunlaşması sağlanırken aynı zamanda bireyler evrensel değerler ve bu değerlerin önemi hakkında bilinçlendirilerek demokratik tutum kazanmaları sağlanır (Çelikkaya ve Demirtaş 2012).

19. Yüzyılın ilk çeyreğinden itibaren Amerika'da kamu okullarında karakter eğitimine yönelik dersler verilmeye başlandı. 1920 yılına gelindiğinde ise Amerika'daki devlet okullarının tamamına yakınında karakter eğitimi etkinlikleri uygulanıyordu (Gooding, 2004). 1940'lara gelindiğinde John Dewey eğitimde etkili oldu ve çocuklara demokratik tutum kazandırmak için ahlak eğitiminin verilmesini savundu (Rodak, 2005'den aktaran: Ekşi ve Katılmış, 2016). 1950'lerde ise ahlak eğitimi etkisini yitirerek pozitivist bilimlerin eğitimi önem kazand1 (Lickona, 1991'den aktaran: Ekşi ve Katılmış, 2016). Değerler Eğitimi ile ilgili yapılan çalışmalar 1970'li yılların ortalarından sonra yayımlanmaya başladı ve 1990'lı yılına gelindiğinde ise toplumsal, ahlaki değerlere verilen önem azalırken bireysel uyum değeri ön plana çıktı (Demircioğlu ve Tokdemir, 2008). Toplumsal sorunların artması nedeniyle 1990'lı y1llardan itibaren karakter eğitimine olan ilgi tekrar arttı (Uysal, 2008).

Değer eğitiminin verilmesinde kullanılan değer akımları değer gerçekleştirme, değer analizi, ahlaki ikilem, karakter eğitimi, vatandaşlık eğitimi, ahlak eğitimidir (Yüksel, 2005). Ahlaki ikilem tekniğinde temel alınan ahlaki değerlerle bu değerlere zit olan durumları açıklamak için kullanılır (Cevizci, 2002). Kohlberg tarafindan ortaya konan bu yaklaşım sonucunda Kohlberg, Ahlaki Gelişim Kuramını ortaya koymuştur (Doğanay, 2009). Ahlaki Gelişim Kuramına göre değerler insanlara dışarıdan başkalarının telkini ile değil kişinin kendisinin bilişsel süreçleri etkin olarak gerçekleştirmesi sonucu kazanacağını savunur ve bunu gerçekleştirirken de çelişkilere yol açan durumlarla karşılaşması karar verme ve muhakeme yeteneklerini geliştirir (Gardiner ve Gander, 2015). Bunu gerçekleştirmek için adil topluluk okulları kuran Kohlberg okullarda adalet, eşitlik ve demokrasi eğitimi vermiştir (Yüksel, 2005). Ahlaki 
ikilem yaklaşımı şu aşamalardan oluşmaktadır (Savage, Armstrong, 1996'den aktaran: Ekși ve Katılmış, 2016).

(i) Ahlaki ikilem anlatan olayın ya da durumun anlatılması

(ii) Öğrencilerden ikilemle alakalı kısa cevapların alınması

(iii) Küçük gruplarda cevapların nedenlerinin tartışılması

(iv) Tüm gruplarda ortaya çıkan görüşlerin nedenlerinin tartışılması

(v) Sınıftaki tüm öğrencilerin kendi düşüncelerini destekleyen nedenleri açıklaması ve tartışmanın sonlanmasi

Ahlaki ikilem tekniğinde öğrenci bir sorunla karşılaşmakta bu sorunu kendi yaşantısı, düşüncesi, sosyal-kültürel durumu, dini ve vicdani özellikleri gibi birçok süzgeçten geçirdikten sonra bir ahlaki yargıya ulaşacaktır (Brimi, 2008). Bu yönüyle Ahlaki ikilem tekniği öğrencinin muhakeme gerektiren durumlardaki tercihini net olarak ortaya koyması açısından önemlidir. Ahlaki ikilemin bu yönü göz önünde bulundurularak yapılan bu çalışma da ahlaki ikilem tekniğinin uygulanması uygun görülmüştür.

Değer hakkındaki yapılan çalışmalarda ahlaki ikilem yaklaşımıyla ilgili çok sayıda tez ve makale bulunmaktadır (Tahiroğlu, 2012; Aktepe ve Tahiroğlu, 2016) yaptıkları çalışmalarda değer eğitiminde etkinliklerden faydalanmanın etili olduğu sonucu ortaya çıkmıştır. Bu çalışmalarda ayrıca değer eğitiminde kullanılabilecek etkinliklerin ihtiyaçları karşılayamadığı kullanılabilecek etkinliklerin sayıca yetersizliği ortaya konmuştur. Yaptığımız bu çalışma ile değerlerin etkinlik yoluyla kazandırılmasını kolaylaştırılacak ve kullanılan etkinliklerin çeşitlenmesine katkıda bulunacaktır. Literatür taraması yapıldığında saygı değerini kapsayan etkinlik çalışmaların yapılmış olduğu, buna karşılık saygı değerinin genel anlamda ele alınması sebebiyle farklılıklara saygı değerine özel çalışmaların yeterli olmadığı görülmüştür. Ayrıca etkinliklerin sınıf seviyesinde ele alınmasının öğrencilerin zihinsel gelişimi ve ahlaki gelişimleri açısından faydalı olacağı düşünüldüğünden çalışmada 7. Sınıflara yönelik bir etkinlik yaprağı hazırlanmış ve bu çalışma yaprağı uygulanarak öğrenci görüşleri alınmıştır. Böylece öğrencilerin yaş ve sınıf seviyelerine göre farklılık gösterebilecek değer yaklaşımlarının daha net anlaşılması amaçlanmıştır. Ayrıca 7.Sınıf öğrencilerinin bulundukları yaş itibari ile yaşadıkları fiziki, biyolojik ve zihinsel değişim öğrencilerin birçoğunun çevresi ile olan ilişkilerini olumsuz etkileyebilmektedir. $\mathrm{Bu}$ olumsuz durumun ortadan kaldırılması için bu dönem öğrencilerinin kendilerindeki ve çevrelerindeki farklı durumları benimsemeleri ve karşılarındaki kişilerin farklılıklarına saygı göstermeleri gerekmektedir. Bu çalışma ile öğrencilerin yaşamış oldukları yaş grubunda farklılıklara sayg1 değerine ilişkin düşünceleri ortaya konulmaya çalışılmıştır.

Literatür taraması yapıldığında Farklılıklara Saygı Değeri ile ilgili doğrudan bir çalışmanın bulunmadığı fakat saygı değerini genel olarak ele alan çalışmaların bulunduğu görülmüştür. Bunlar arasında Baysal ve Saman (2010) "İlkögrretim beşinci sınıf öğrencileri ile değerler üzerine bir çalışma" başlıklı çalışmalarında araştırmaya katılan öğrencilerin çoğu çevreye saygı ile insana saygı değerini ilişkilendirmişler ve saygı değerini vurgulayan ifadeler kullanmışlardır. Candan ve Ergen (2014) “3. sınıf hayat bilgisi ders kitaplarının temel evrensel değerleri içermesi bakımından incelenmesi" adlı çalışmalarında ise 3.Sınıf Hayat Bilgisi birinci kitapta saygı değeri ile ilgili olarak 30 yazılı ifade ile 11 resmin; ikinci kitapta ise 17 yazılı ifade ile 3 adet resmin toplamda bu değerin 61 farklı yerde işlendiği görülmektedir. Burada aile üyelerine olan saygının yanında, saygının bir diğer türü olan kişisel haklara saygının da vurgulandığı ortaya konulmuştur. Yiğittir (2010) “ilköğretim ögrenci velilerinin okullarda kazandırılmasını arzuladı̆̆ değerler" isimli çalışmada veliler çocuklarında olmasını arzuladıkları değerleri çalışkanlık, saygılı olma, bayrağa ve İstiklal Marşına saygılı olma, vatanseverlik, iyi insan olma, etkin vatandaş olma, sorumluluk, başarılı olma, yardımseverlik şeklinde sıralamışlardır.

Okulların öğrencilere kazandırmayı amaçladığı eğitim ve öğretim faaliyetleri göz önüne alındığında, değerler eğitimi önemli bir yer tutmaktadır. Bu değerlerin öğrencilere kazandırılmasının gerekliliği birçok öğretim tekniğinin kullanılmasının önünü açmıştır. Bu tekniklerden biri de ahlaki ikilem tekniğidir. Bu teknikle öğrenci karşılaştığı değer sorununa kendi yaşantısı ve muhakeme kabiliyetine bağlı olarak çözüm üretir, bireysel çıkarımlarda bulunur. Buradan hareketle, bu araştırmada ahlaki ikilem tekniğine dayalı hazırlanan farklılıklara saygı değeri çalışma yaprağındaki sorulara verilen öğrenci cevaplarının tespit edilmesi amaçlanmıştır.

\section{Yöntem}

Nitel bir çalışma olan bu araştırmada örnek olay yöntemi kullanılmıştır. Araştırma bütüncül tek durum deseni ile yürütülmüştür. Örnek olay yöntemi durum çalışması olarak da isimlendirilmektedir. Durum çalışması şu şekilde tanımlanmaktadır. Güncel bir olguyu kendi yaşam çerçevesi içinde çalışan, olgu ve içinde bulunduğu içerik arasındaki sınırların kesin hatlarıyla belirgin olmadığ 1 ve birden fazla kanıt ve veri kaynağının mevcut olduğu durumlarda görgül bir araştırma yöntemidir (Yin, 1986'den aktaran: Yıldırım ve Şimşek, 2016). Örnek olay yönteminin uygulama aşamaları; sorunun bulunması sorunun tanımlanması, çözüm geliştirilmesi, çözümün uygulanması ve değerlendirilmesi ve sonuçların paylaşılması şeklindedir (Büyüköztürk vd., 2016).

\section{1. Çalışma Grubu}

Araştırmanın çalışma grubunu Nevşehir merkezindeki bir devlet okulunun yedinci sınıfında öğrenim gören yirmi yedi (27) öğrenci oluşturmaktadır. Öğrencilerin on altısı (16) kız, on biri (11) erkektir. Öğrencilerin cinsiyetlere göre dağılımı aşağıdaki tabloda verilmiştir.

Tablo 1. Öğrencilerin Cinsiyetlere Göre Dağılımı

\begin{tabular}{cccc}
\hline Sinıf & Kiz & Erkek & Toplam \\
\hline $7 / \mathrm{B}$ & 16 & 11 & 27 \\
\hline
\end{tabular}




\subsection{Veri Toplama Arac1}

Veri toplama aracı olarak araştırmacılar tarafindan hazırlanan "Farklılıklara saygı çalışma yaprağı" kullanılmıştır. Çalışma yaprağı, ahlaki ikilem tekniğine dayalı olarak birbirine zıt iki farklı hikâye ve bu hikâyelere ilişsin 4 tane açık uçlu sorudan oluşmaktadır. Etkinlik görsellerle özlü sözlerle desteklenmiştir. $\mathrm{Bu}$ sorular; 1 . Hikâyelerde yer alan sinıflardan hangisinde yer almak isterdiniz, neden? 2. Sizce, hangi sinıfta farklılıklara saygll bir ortam var, neden? 3. İkinci hikâyedeki sınıfin ögretmeni olsaydınız hangi durumu seçerdiniz, neden? 4. Siz sorunu çözmek için başka neler yapardınız? Araştırmacılar tarafindan veri toplama aracı hazırlanmıştır. Sorular hazırlanırken uzman görüşlerinden yararlanılmış ve gelen görüşler doğrultusunda veri toplama aracı oluşturulmuştur. $\mathrm{Bu}$ anlamda kapsam geçerliliği sağlanmıştır. Ayrıca veri toplama aracının güvenilirliğinin belirlenmesinde uyuşum yüzdesinden yararlanılmıştır. Miles ve Huberman'ın (1994) Uyuşum yüzdesi=Görüş birliği/Görüş birliği+Görüş ayrılığ1, formlü kullanılmıştır. Yıldırım ve Şimşek (2016) güvenilirlik hesaplamasında uyuşum yüzdesi \%70 olduğunda güvenilirlik yüzdesine ulaşılmış olduğunu belirtmektedir. Veri toplama aracinda bulunan her bir soru için bu oran \%70'in üzerindedir. Bu anlamda veri toplama aracının geçerli ve güvenilir olduğu söylenebilir.

\subsection{Verilerin Analizi}

Elde edilen verilere içerik analizi yapılmıştır. Cümleler alt alta yazılarak benzerlik taşıyan ifadeler bir araya getirilmiştir. Bir araya getirilen ifadeler için temalar oluşturulmuştur. "Hikâyelerde yer alan sinıflardan hangisinde yer almak isterdiniz. Neden?" sorusuna 6/A sınıfını seçen öğrencilerin verdikleri cevaplardan oluşturulan temalar şu şekildedir. "Ali ile arkadaş olurdum" "Alay edenleri engellemek isterdim" "Aliye yardımc olurdum" 6/B sınıfını seçen öğrencilerin verdikleri cevaplar sonucu oluşturulan temalar "Saygllılar" "İyi davrantyorlar" "Birliktelik var" "Daha mutlu olurdum" "Yardımseverler" "Dostluk var" şeklinde olmuştur. Her iki sınıfta da olmak istemeyen öğrencinin cevabı ise "Ali konuşamıyor Ayşe de yürüyemiyor." teması altında toplanıştır. Öğrencilerin "Sizce hangi sinıfta farklılıklara saygl var, neden?" Sorusuna öğrencilerin tamamı 6/B sınıfı olarak cevap vermiştir. Öğrencilerin "Neden" sorusuna verdikleri cevaplar şu temalar altında toplanmıştır: "Alay etmiyorlar küçümsemiyorlar" "Saygılılar" "yardımcı oluyorlar" "İyi Davranıyorlar" "Alay etmiyorlar küçümsemiyorlar". Öğrencilerin "Siz bu sınıfın öğretmeni olsaydınız hangi çözüm yolunu seçerdiniz neden" sorusuna öğrencilerin tamamı hikâye de geçen çözüm ikiyi seçmişlerdir. "Neden" sorusuna verdikleri cevaplar sonucu oluşturulan temalar "Farklılıklara saygı" "Empati" "olumlu iletişim" temaları altında toplanmıştır. Öğrencilerin "Siz sorunu çözmek için başka neler yapardınız?" sorusuna verdiği cevaplar sonucu oluşturulan temalar şu şekildedir: "Dilan'a diksiyon dersi verirdim" "Dilan'ın dil ve kültürel gelişimini săglardım" "Dilan'ın sınıfını değiştirirdim”, " Dilan'a İmir' $i$ tanıtırdım”, “Dışlanmasını önlerdim”, “Arkadaşlı̆̆ın nasıl olması gerektiği konusunda ders anlatırdım”, "Empati kurmalarını sağlardım”, "Dilan'ın arkadaşlarıyla kaynaşmasını ve birbirlerini daha iyi tanımalarını sağlayacak etkinlikler yaptırırdım", "Saygıll ve merhametli olmalarını rica ederdim”, "Dilan'ın geldiği şehri araştırtıp onu anlamalarını sağlardım”, "Kaynaşmalarını sağlayacak yeni oyunlar geliştirirdim", "fark edilmesini sağlardım”.

Oluşturulan temalar hakkında aynı alanda çalışan başka araştırmacıların hakemliğine başvurulmuştur. Görüşleri doğrultusunda düzenlemeler yapılmıştır. Böylece araştırmanın güvenilirliğinin sağlanması amaçlanmıştır. Araştırmanın bulgularının iç güvenilirliğini ve geçerliliğini arttırmak amacıyla öğrencilerin görüşlerine temaların altında doğrudan alıntılar yapılarak yer verilmiştir.

\section{Bulgular}

Öğrencilerin farklılıklara saygı değerini kazanmaları için hazırlanmış olan etkinlikteki sorulara verdikleri cevaplar bu bölümde yer almaktadır.

\subsection{Yukarıdaki hangi sınıfta olmak isterdiniz?}

Öğrenciler hangi sınıfta olmak isterdiniz sorusuna 6/A sinıfinda olmak isterdim, 6/B sinıfinda olmak isterdim ve her iki sınıfta da olmak istemezdim şeklinde cevap vermişlerdir.

Tablo 2. Öğrencilerin Sınıf Tercihleriyle İlgili Görüşleri

\begin{tabular}{cccccccc}
\hline & \multicolumn{2}{c}{$6 / \mathrm{A}$} & & \multicolumn{2}{c}{$6 / \mathrm{B}$} & \multicolumn{2}{c}{ Hiçbiri } \\
\hline \multirow{2}{*}{ Öğrenci } & $\%$ & $\mathrm{f}$ & $\%$ & $\mathrm{f}$ & $\%$ & $\mathrm{f}$ \\
\cline { 2 - 7 } & 25,9 & 7 & 70,3 & 19 & 3,7 & 1 \\
\hline
\end{tabular}

Öğrenciler "Hikâyelerde yer alan sinıflardan hangisinde yer almak isterdiniz" sorusuna 6/A (\%25,9) olmak isterdim, 6/B $(\% 70,3)$ sinıfinda olmak isterdim ve her iki $(3,7)$ sinıfta da olmak istemezdim şeklinde cevap vermişlerdir

Bazı öğrencilerin cevapları aşağıdaki gibidir;

Öğrenci 13: 6/A sinıfinı seçerdim çünkü Ali ile arkadaş olurdum.6/B de herkes Ayşe ile ilgileniyor fakat Ali'yi dişliyorlar.

Öğrenci 3: 6/B Sınıfinda olmak isterdim çünkü saygllı ve merhametli bir sinif.

Öğrenci 24: Íkisinde de olmak istemezdim Ali konuşamıyor Ayşe de yürüyemiyor.

6/A sınıfını seçen öğrenciler seçme nedenlerini; Ali’ye yardımcı olurdum, Alay edenleri engellerdim, Ali ile arkadaş olurdum şeklinde belirtmişlerdir.

6/A Sınıfını seçen bazı öğrencilerin cevabı aşağıdaki gibidir;

Öğrenci 13: Ali ile arkadaş olurdum.6/B de herkes Ayşe ile ilgileniyor fakat Ali'yi dişlıyorlar.

Ögrrenci 26: Alay edenleri engellemek isterdim.

Öğrenci 14: Aliye yardımci olurdum. 
Şekil 1. Öğrencilerin 6/A Sınıfını Seçme Nedenleri

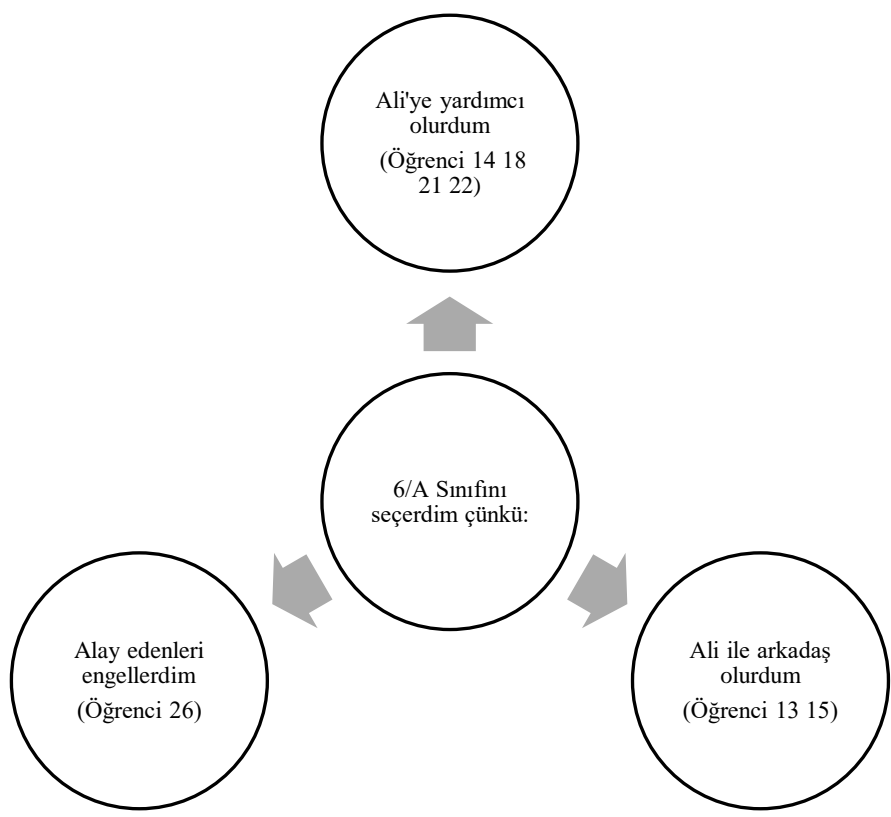

6/B sınıfını seçen öğrenciler seçme nedenlerini iyi davranıyorlar, yardımseverler, daha mutlu olurdum, saygılılar, dostluk ve birliktelik var şeklinde belirtmişlerdir.

Şekil 2. Öğrencilerin 6/B Sınıfını Seçme Nedenleri

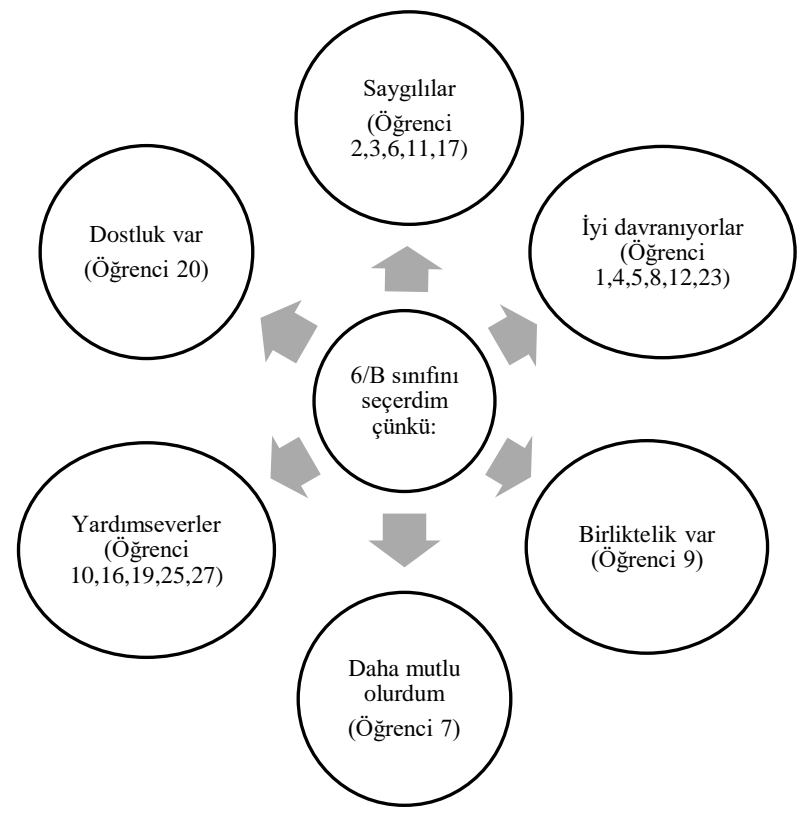

6/B Sınıfını seçen bazı öğrencilerin cevabı aşağıdaki gibidir;

Öğrenci 1: Çok iyi davranlyorlar.

Öğrenci 27: Arkadaşlarına yardim eden sinifi seçerdim. Çünkü yardımlaşma önemli.

Öğrenci 7: Daha mutlu ve başarılı olurum.

Öğrenci 2: Farklllıklara saygı var.

Öğrenci 20: 6/B de dostluk var.

Öğrenci 9: Sinufta birlik ve beraberlik var.

"Her iki sınıfta da olmak istemezdim çünkü:" cevabını veren bir öğrenci vardır. Bu cevabının nedenini de 6/A sınıfındaki öğrencinin konuşamaması 6/A sınıfındaki öğrencinin de yürüyememesi sebebiyle olduğunu belirtmiştir.

Şekil 3. Öğrencilerin Her İki Sınıfı Seçmeme Nedenleri

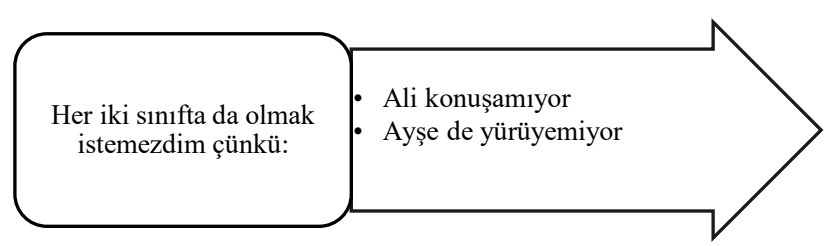

Her ki sınıfta da olmak istemeyen öğrencinin cevabı:

Öğrenci 24: Ali konuşamıyor Ayşe de yürüyemiyor.

3.2. Sizce hangi sinıfta farklılıklara sayg1 var. Neden?

$\mathrm{Bu}$ soruya öğrencilerin tamamı 6/B sınıfinı seçerdim şeklinde cevap vermiştir. 6/B sınıfını seçen öğrenciler ise 6/B sınıfını seçme nedenlerini ise saygılılar, alay etmiyorlar küçümsemiyorlar, daha iyi davranıyorlar, yardımcı oluyorlar şeklinde belirtmişlerdir.

Şekil 4. Öğrencilerin "Sizce Hangi Sınıfta Farklılıklara Saygı Var Neden?" Sorusuna Verdiği Cevaplar

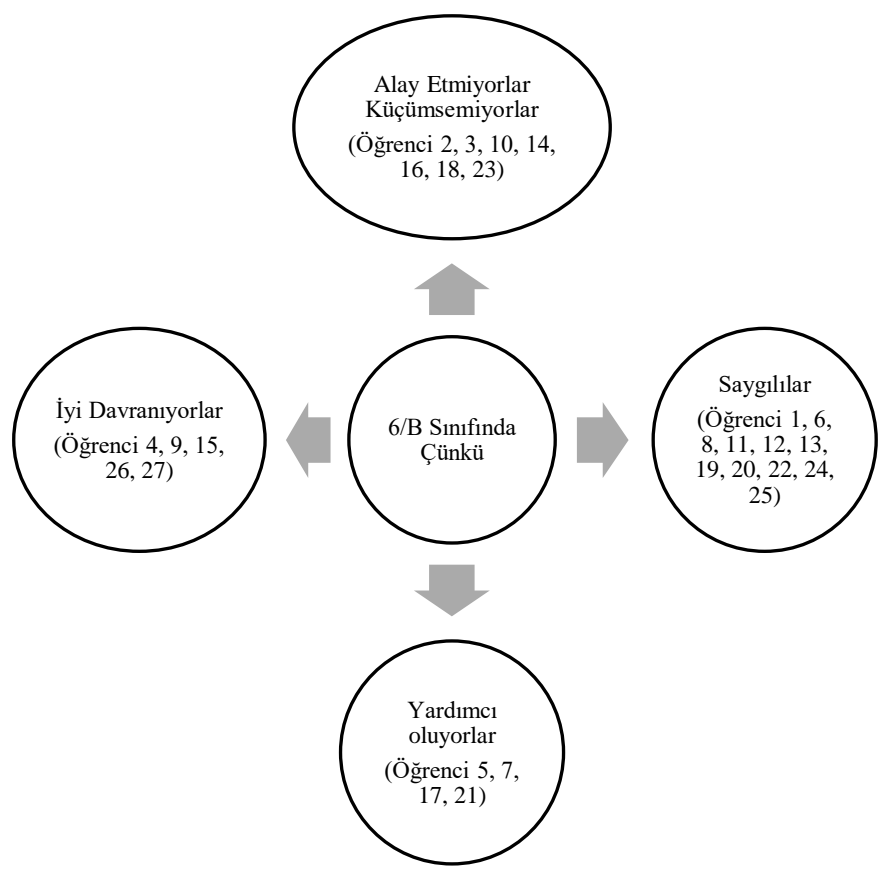

"Sizce; hangi sinufta farkllliklara saygll bir ortam vardır, neden?" sorusuna öğrencilerin tamamı 6/B sinıfi olarak cevap vermiştir. Seçme nedenlerini ise saygı $(\% 40,7)$, alay etmeme ve küçümsememe $(\% 25,9)$, iyi davranış $(\% 18,5)$, yardımcı olma $(\% 14,8)$ şeklinde ifade etmişlerdir.

6/B sınıfını seçen bazı öğrencilerin cevapları;

Öğrenci 8: Yürüyemeyen arkadaşlarına saygı gösteriyorlar.

Öğrenci 18: Arkadaşlarlyla alay etmiyorlar.

Öğrenci 17: Herkes engelli arkadaşına yardım ediyor. 


\section{Öğrenci 4: Ayşe’ye çok iyi davranıyorlar}

3.3. Siz bu sınıfın öğretmeni olsaydınız hangi çözüm yolunu seçerdiniz? Neden?

$\mathrm{Bu}$ soruya öğrencilerin tamamı çözüm ikiyi seçeceklerini belirtmişlerdir. Çözüm ikiyi seçmelerinin nedeni olarak da farklılıklara saygı duyulmalı, olaylara empati ile bakılmalı, bulunulan ortamlarda insanlarla olumlu iletişim kurulmalıdır şeklinde belirtmişlerdir.

Şekil 5. Öğrencilerin "Siz Bu Sınıfın Öğretmeni Olsaydınız Hangi Çözüm Yolunu Seçerdiniz Neden” Sorusuna Verdiği Cevaplar

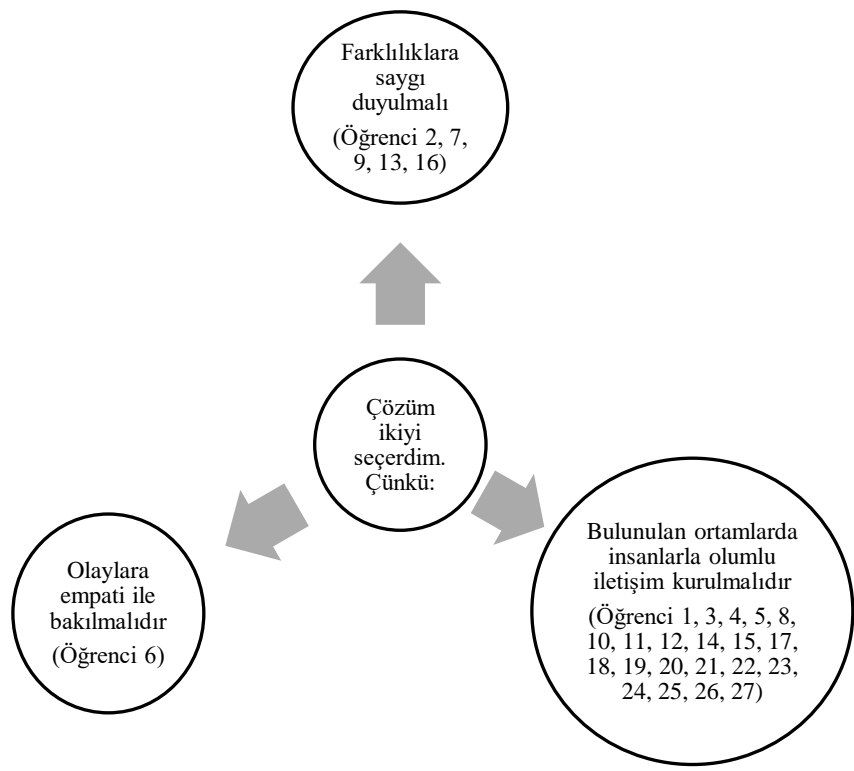

"Ikinci hikâyedeki sınıfın öğretmeni olsaydınız hangi durumu seçerdiniz, neden?" sorusuna öğrencilerin tamamı çözüm ikiyi yani "Dilan'ın arkadaşlarıyla kaynaşmasını ve birbirlerini daha iyi tanımalarını sağlayacak etkinlikler yaptırırdım" seçeneğini seçmişlerdir. Çözüm ikiyi seçmelerinin nedeni olarak da farklılıklara saygı $(\% 18,5)$, empati $(\% 3,8)$, olumlu iletişim $(\% 77,7)$ olarak ifade etmişlerdir.

Öğrencilerin verdikleri cevapların bazıları aşağıdaki gibidir;

\section{Öğrenci 17: Sınıfımda kimsenin dışlanmasını istemezdim.}

\section{Öğrenci 9: Herkes farlıdır öyle kabul etmeliyiz}

Öğrenci 6: Arkadaşlarına Dilan'ın yerine kendilerini koyup nasıl hissettiklerini sorardım.

\subsection{Siz Sorunu Çözmek İçin Başka Neler Yapardinı?}

Öğrenciler bu soruya Birlikte faaliyet yapardım, Dilan'a diksiyon dersi verirdim, Dilan'ın dil ve kültürel gelişimini sağlardım, Dilan'ın sınıfını değiştirirdim, Dilan'a İzmir'i tanıtırdım, dışlanmasını önlerdim, arkadaşlığın nasıl olması gerektiği konusunda ders anlatırdım, empati kurmalarını sağlardım, 2.çözümü kullanırdım, saygılı ve merhametli olmalarını rica ederdim, Dilan'ın geldiği şehri araştırtıp onu anlamalarını sağlardım, kaynaşmalarını sağlayacak yeni oyunlar geliştirirdim, fark edilmesini sağlardım şeklinde cevaplar vermişlerdir.
Şekil 6. Öğrencilerin "Siz Sorunu Çözmek İçin Başka Neler Yapardınız?" Sorusuna Verdiği Cevaplar

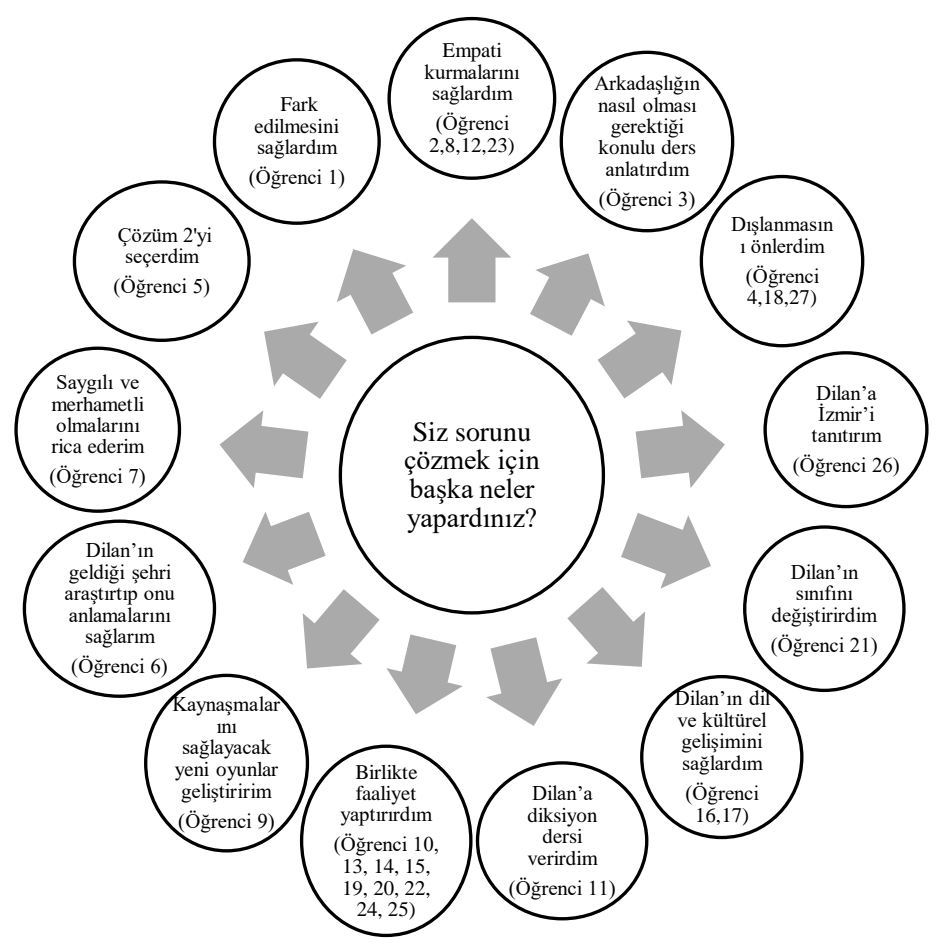

"Siz sorunu çözmek için başka neler yapardınız?" sorusuna ise birlikte faaliyet yapardım $(\% 33,3)$, Dilan'a diksiyon $(\% 3,7)$ dersi verirdim, Dilan'ın dil ve kültürel gelişimini sağlardım $(\% 7,4)$, Dilan'ın sınıfını değiştirirdim $(\% 3,7)$, Dilan'a İzmir'i tanıtırdım $(\% 3,7)$, dışlanmasını önlerdim $(\% 11,1)$, arkadaşlığın nasıl olması gerektiği konusunda ders anlatırdım $(\% 3,7)$, empati kurmalarını sağlardım $(\% 14,8)$, Dilan'ın arkadaşlarıyla kaynaşmasını ve birbirlerini daha iyi tanımalarını sağlayacak etkinlikler yaptırırdım \%3,7), saygılı ve merhametli olmalarını rica ederdim $(\% 3,7)$, Dilan'ın geldiği şehri araştırtıp onu anlamalarını sağlardım $(\% 3,7)$, kaynaşmalarını sağlayacak yeni oyunlar geliştirirdim $(\% 3,7)$, fark edilmesini sağlardım $(\% 3,7)$ şeklinde cevaplar vermişlerdir.

Öğrencilerin bu soruya verdikleri cevaplardan bazıları aşağıdaki gibidir;

Öğrenci 10: Onlarla beraber bir faaliyete katılırdık oyunlar oynar eğlenirdik.

Öğrenci 11: Dilan'a diksiyon dersi vererek daha düzgün konuşmasını sağlardım.

Öğrenci 16: Ders içinde o çocuğun dil ve kültürünü arttırırdım ve birbirlerinin dil ve kültürünü anlayınca dışlanma ortadan kalkardl.

Öğrenci 21: Dilan'ın sınıfını değiştirirdim.

Öğrenci 26: Dilan'a İzmir öğelerini tanıtmaya ve sevdirmeye çalışırdım.

Öğrenci 18: Arkadaşlarının yanına gider onunla arkadaş olmalarını söylerdim.

Öğrenci 3: Mesela herhangi bir derste arkadaşlığın nasıl olduğunu ve dışlamamayı anlatarak çözüm bulabilirdim. 
Öğrenci 8: O sinıftaki öğrencilerle konuşup kendilerini onun yerine koymalarını isterdim.

Öğrenci 5: 2. çözümü kullanırdım.

Öğrenci 7: Dilan ’la konuşup üzülmemesini söylerdim sonra sinıftakilerle konuşup saygll ve merhametli olmalarını rica ederdim.

Öğrenci 6: Arkadaşlarına Dilan'ın hangi şehirden olduğunu araştırıp o şehrin geleneklerine bakıp Dilan'la yakınlaşmalarını sağlardım.

Öğrenci 1: Dilan'ın arkadaşları tarafindan fark edilip aralarına almalarını sağlardım.

Öğrenci 9: Yeni oyunlar geliştirirdim çünkü sınıf böyle daha iyi alışır ve anlaşır.

\section{Sonuç ve Öneriler}

Araştırmada öğrencilere verilen etkinlikte yer alan ve iki farklı ahlaki davranış bildiren hikâyeden yola çıkarak sorulan "Hangi sinıfta yer almak isterdiniz?" sorusuna öğrencilerin \% 70,3 'nün olumlu ve kabul edilebilir ahlaki davranış gösterilen sınıfta yer emlak istedikleri ortaya çıkmıştır. Bu da öğrencilerin ahlaki değerleri göz önünde bulundurarak bir tercih yaptıklarını ortaya koymaktadır. \%25,9 u karşı sınıfta yer almak istemişler fakat bu sınıfı tercih etme amaçlarını sınıfta zor durumdaki arkadaşlarına yardımcı olmak olarak belirtmişlerdir. Buradan hareketle de öğrencilerin çevrelerinde yaşanan olumsuz ahlaki durumlara karşı kayıtsız kalmadıkları anlaşılmaktadır. Çalışmada ahlaki ikilem bildiren hikâyelerden her iki sınıfta da olmak istemeyen bir öğrenci bulunmaktadır. Bu öğrenci \%3,7 bir oranı temsil etmektedir. Öğrenci gerekçesini hikâyede geçen kahramanlardan birinin yürüyememesi diğerinin konuşamaması olarak belirtmiştir. $\mathrm{Bu}$ öğrencinin davranışından hareketle öğrencilerin olumsuz ve kabul etmek istemedikleri durumların bulunduğu ortamlardan uzaklaşma eğiliminde oldukları da ifade edilebilir. Genel olarak öğrencilerin soruya verdiği cevaplar 1şı̆̆ında değerlendirildiğinde öğrencilerin değer algılarında saygı (farklılıklara saygı ve hak ve özgürlüklere saygı) değerinin önemli olduğu ve farklılıklara saygılı bir ortamda bulunmak istedikleri ortaya çıkmıştır. Tay, Durmaz ve Şanal (2013) yaptıkları çalışmada öğrencilerin değeri anlatmada en çok kullandıkları ifadeler; sevgi, saygı, aile, dostluk, para ve çalışkanlık olurken en az ise; estetik, güvenirlik, kültürel miras ve inanç değerleri olmuştur. Araştırmanın sonucu da göstermektedir ki, saygı değeri öğrenciler için değer eğitiminde önde gelen değerler arasındadır. Yiğittir ve Öcal (2010) "İlköğretim 6. sınıf öğrencilerinin değer yönelimleri" adlı çalışmada öğrencilerin değer yönelimleri arasında saygı değerinin bulunduğu ortaya çıkmıştır. Çelikkaya ve Filoğlu (2014) "Sosyal bilgiler öğretmenlerinin değere ve değer eğitimine ilişkin görüşleri" başlıklı çalışmada da sosyal bilgiler öğretmenlerinin sosyal bilgiler dersi programında var olan değerlerden öncelikli olarak kazandırılması gereken değerlere ilişkin öğretmenlerin görüşleri sıralamasında saygı değerini ilk sırayı aldığı görülmektedir.

Çalışmamızda öğrencilere yönelttiğimiz "Sizce hangi sınıfta farklılıklara sayg1 var? Neden?" sorusuna verdikleri cevaplardan anlaşıldığı üzere alay etmemeyi, küçümsememeyi, saygılı olmayı, yardımcı olmayı, iyi davranmayı farklılıklara saygılı olmanın bir göstergesi olarak ifade etmișlerdir. $\mathrm{Bu}$ davranışlara öncelik vermişlerdir. Aydın (2003) yaptığg araştırmada da modern değerlerden özgürlük, kendine sayg1, insan hakları gibi kişiselliği olan değerlerin ön plana çıktığı görülmüştür. Yaptığımız çalışma da değerlerin temelini oluşturan saygı, yardımseverlik gibi değerlerin öğrencilerin değer algılarında önemli bir yere sahip olduğu görülmektedir.

Çalışmamızda ayrıca öğrencilerin ikinci hikâyedeki "Sınıfın öğretmeni olsaydınız hangi durumu seçerdiniz. Neden?" Sorusuna verdikleri cevaplar değerlendirildiğinde öğrencilerin, ahlaki muhakeme gerektiren durumlarda karar verirken farklılıklara saygıyla bakılmasının, olaya empatiyle yaklaşılmasının ve olumlu iletişim kurmanın etkili olması gerektiğini ortaya koymuşlardır. Nitekim Baysal ve Saman (2013) yaptıkları çalışmada öğrencilerin olaylara yaklaşırken ve değerlendirirken saygı ve empatiyle yaklaştıkları görülmektedir. $\mathrm{Bu}$ çalışma araştırmanın sonuçlarını destekler niteliktedir. Öğrenciler sorunların çözümünde empati kurmanın önemli olduğunu ifade etmişlerdir.

Öğrenciler "Siz sorunu çözmek için başka neler yapardınız?" Sorusuna verdikleri cevaplarla çözüm sürecinde olumsuz bir ahlaki durumun ortadan kaldırılması için sorun yaşayan kişiye destek olmak, bulunulan ortamı değiştirmek veya ortamdaki iletişimi ve işbirliğini artırmak yoluyla çözüme ulaşmak yönünde önerilerde bulunmuşlardır. Bu önerilerde bize öğrencilerin ahlaki ve toplumsal kurallara uygun hareket ettiklerini ve bu kurallara aykırı olmayan uygulanabilir çözüm önerileri sunduklarını ortaya koymuştur. $\mathrm{Bu}$ da değer eğitimi çalışmalarının öğrencilerin ahlaki değerlere karşı olumlu tutum geliştirmelerini sağladığını ortaya koymaktadır.

Sonuç olarak araştırmamızda öğrencilerin ahlaki muhakeme gerektiren durumlarda olumlu ahlaki davranışı gösterme eğiliminde oldukları ortaya çıkmıştır. $\mathrm{Bu}$ durumlarla karşılaştıklarında empatiyle ve farklılıklara saygılı bir anlayışla yaklaşmayı tercih etmektedirler. Karşılaştıkları ahlaki muhakeme gerektiren durumlarda olası çözüm yolları üretebilmektedirler. Bu bağlamda öğrencilerin "Hikayelerde yer alan sinıflardan hangisinde yer almak isterdiniz?" sorusuna verdiği cevaplardan oluşturulan temalar şu şekildedir: Arkadaşlık, yardımseverlik, saygı, iyi davranma, birlik olma ve dostluk. Öğrencilerin "Sizce hangi sınıfta farklılıklara saygı var, neden?" sorusuna göre oluşan temalar ise: Alay etmeme, küçümsememe, iyi davranma, saygılı olma ve yardımsever olmadır. Öğrencilerin "Siz sorunu çözmek için başka neler yapardınız?" sorusuna verdiği cevaplarda oluşan temalar: Farklılıklara saygı duyma ve empatik olmadır.

Araştırma sonucuyla ilgili öneriler: Öğrencilere "Ahlaki muhakeme" gerektiren etkinliklerin yapılması önerilir. Okul ve sınıf içinde işbirliği ve yardımlaşmanın artırılması, öğrencilerde empati ve saygılı olma değerlerinin gelişine yararlı olabilir. Değerlerin kazanımında "Ahlaki muhakeme" yaklaşımıyla sınıf içi etkinliklerin yanında onların duygusal gelişimlerine katkı sağlayacak ve olumlu düşüncelere yönlendirecek "Tiyatro, sinema ve konferans" gibi sosyal aktivitelerde yer alamsı faydalı olabilir. Öğrencilerin okul veya sınıf ortamında oluşacak olumsuz durumlardan etkilendikleri ve bu ortamda bulunmak istemedikleri anlaşılmaktadır. Bu sebeple okul ve sınıf atmosferinin olabildiğince olumlu hale getirilmesi gerekmektedir. 


\section{Kaynakça}

Aktepe, V., \& Tahiroğlu, M. (2016). Değerler Eğitimi Yaklaşımları ve Etkinlik Örnekleri. The Journal of Academic Social Science Studies, 42, 361-384.

Aydın, M. (2003). Gençliğin Değer Algısı: Konya örneği. Değerler Ĕ̈itimi Dergisi, 1(3), 121-144.

Aydın, M. Z. (2010). Okulda Değerler Eğitimi. Eğitime Bakış Dergisi, 6(18), 16-19.

Baysal, N. Z., \& Saman, O. (2010). İlköğretim 5. Sınıf Öğrencileri ile Değerler Üzerine Bir Çalışma. Elektronik Sosyal Bilimler Dergisi, 9 (34), 056-069.

Bilgin, N. (1995). Sosyal Psikolojide Yöntem ve Pratik Çalışmalar. İstanbul: Sistem Yayıncılık.

Brimi, H. (2008). Academic Instructors or Moral Guides? Moral Education in America and Teacher's Dilemma. The Clearing House, 82(3), 125-130.

Büyüköztürk, Ş., Çakmak, E., Akgün, Ö. E., Karadeniz, Ş., \& Demirel, F. (2016). Bilimsel Araştırma Yöntemleri. Ankara: Pegem Akademi Yayınları.

Candan, D., \& Ergen, G. (2014). 3. Sınıf Hayat Bilgisi Ders Kitaplarının Temel Evrensel Değerleri İçermesi Bakımından İncelenmesi. Uşak Üniversitesi Sosyal Bilimler Dergisi, 7(1), 134-161

Cevizci, A. (2002). Paradigma Felsefe Sözlüğü. İstanbul: Paradigma Yayınları.

Çelikkaya, T., \& Demirtaş, Ç. (2012). Sosyal Bilgiler Öğretmen Adaylarının Programdaki Değerlere İlişkin Algısal Farkındalıkları. The Journal of Academic Social Science Studies, 5(8), 415-427.

Çelikkaya, T., \& Filoğlu, S. (2014). Sosyal Bilgiler Öğretmenlerinin Değere ve Değer Eğitimine İlişkin Görüşleri. Kuram ve Uygulamada Eğitim Bilimleri, 14(4), 1541-1556.

Demircioğlu, İ. H., \& Tokdemir, M. A. (2008). Değerlerin Oluşturulması Sürecinde Tarih Eğitimi: Amaç, İşlev ve İçerik. Değerler Ĕgitimi Dergisi, 6(15), 69-88.

Demirel, Ö. (2007). Kuramdan Uygulamaya Eğitimde Program Geliştirme. Ankara: PegemA Yayıncılık.

Doğanay, A. (2009). Değerler Eğitimi. İçinde: C. Öztürk (Der). Sosyal Bilgiler Öğretimi Demokratik Vatandaşlık Eğitimi. Ankara: PegemA Yayıncılık.

Ekşi, H., \& Katılmış, A. (2016). Uygulama Örnekleriyle Değerler Ĕ̆itimi. Ankara.

Gardiner, H. W., \& Gander, M. J. (2015). Çocuk ve Ergen Gelişimi. Ankara: İmge yayınları.

Gooding, T. F. (2004). Character Education: Perceptions of Social Skills Acquisition in Two Elementary Schools. Doktorate Thesis. USA: Arizona State University.

Hökelekli, H. (2011). Ailede, Okulda, Toplumda Değerler Psikolojisi ve Eğitimi. İstanbul: Timaş Yayınları.

Kale, N. (2009). Felsefiyat. Ankara: Pegem Akademi.

Köylü, M. (2016). Teoriden Pratiğe Değerler Eğitimi. İstanbul: Nobel Yayınları.
Kuçuradi, İ. (1971). Insan ve Değeri. İstanbul: Yank1 Yayınları.

Kuşdil, M. E., \& Kağıtçıbaşı, Ç. (2000). Türk Öğretmenlerin Değer Yönelimleri ve Schwartz Değer Kuramı. Türk Psikoloji Dergisi, 15(45), 59-76.

Mehmetoğlu, A. U. (2006). Gençlik, Değerler ve Din. İçinde: Y. Mehmetoğlu \& A. U. Mehmetoğlu (Ed.), Küreselleşme Ahlak ve Değerler. İstanbul: Litera Yayıncilık.

Miles, M. B., \& Huberman, A. M. (1994). Qualitative Data Analysis: An Expanded Source Book (Second Edition). Thousand Oaks, CA: Sage Publications.

Tahiroğlu, M. (2012). Değerler Eğitiminin İlköğretim 4. Sınıf Öğrencilerinin Trafik Kurallarına Yönelik Tutumlarına Etkisi. Mersin Üniversitesi Eğitim Fakültesi Dergisi, 8(1), 123 -136.

Tay, B., Durmaz, F. Z., \& Şanal, M. (2013). Sosyal Bilgiler Dersi Kapsamında Öğrencilerin Değer ve Değerler Eğitimine İlişkin Görüşleri. Gazi Üniversitesi Gazi Ĕ̆itim Fakültesi Dergisi, 33(1), 67-93.

TDK (2011). Türkçe Sözlük. Ankara: Türk Dil Kurumu Yayınları.

Tepe, H. (2002). Değerler ve Değerler Bilgisi. Ş. Yalçın (Der.) Bilgi ve Değer, Ankara: Vadi Yayınları.

Tillman, D. (2000). 8-14 Yaş Grubu Öğrencileri Iç̧in Yaşayan Değer Ĕgitimi Etkinlikleri, (Çev. Edit. Vedat Aktepe). Konya: Eğitim Yayınevi.

Toku, N. (2003). Değerlerin Dilemması: Sübjektiflik ve Objektiflik. İçinde: Ş. Yalçın (Ed.), Bilgi ve Değer Sempozyum Bildirileri. Ankara: Vadi Yayınları.

Ulusoy, K., \& Dilmaç, B. (2016). Değerler Eğitimi (4.baskı). Ankara: Pegem Akademi.

Uysal, F. (2008). Karakter Eğitimi Programlarının Değerlendirilmesi. Yüksek Lisans Tezi. İstanbul: Yeditepe Üniversitesi.

Ülken, H. Z. (2001). Bilgi ve Değer (2.bask1). İstanbul: Ülken Yayınları.

Yıldırım, A., \& Şimşek, A. (2016). Sosyal Bilimlerde Nitel Araştırma Yöntemleri. Ankara: Seçkin Yayınları.

Yiğittir, S. (2010). İlköğretim Öğrenci Velilerinin Okullarda Kazandırılmasını Arzuladığı Değerler. Değerler Eğitimi Dergisi, 8(19), 207-223.

Yiğittir, S., \& Öcal, A.(2010). İlköğretim 6. Sinıf Öğrencilerinin Değer Yönelimleri. Selçuk Üniversitesi Sosyal Bilimler Enstitüsü Dergisi, 24, 407-416.

Yüksel, S. (2005). Kohlberg ve Ahlak Eğitiminde Örtük Program: Yeni İlköğretim Programlarında Yer Alan Ahlaki Değerleri Kazandırmak İçin Bir Açılım. Kuram ve Uygulamada Eğitim Bilimleri, 5(2), 307-338. 